Al-Fikra: Jurnal Ilmiah Keislaman, Vol. 4, No. 1, Januari-Juni 2005

\title{
EKONOMI ISLAM ANTARA PELUANG DAN TANTANGAN KE DEPAN
}

\author{
Alaiddin Koto
}

\begin{abstract}
Among the law system of life that man needs is economic system as a system pertaining with issues around kinds of prices, spreading of income, work opportunity, monetary, trade, etc. Capitalism and socialism economics systems are systems that were introduced for a long time ago, but now the facts prove that capitalism system is not actually needed by human being. Islamic Economics is an alternative system that emphasizes principle of justice in which benefit and welfare for all together, not for personal or individual interests by allowing any way. The efforts to introduce the Islamic economy are intensifying its socialization, increasing appeal, preparing human resources that skilled in civil works and possess scientifically sufficient vision and doing lobbies on "high level" business politics among the public opinion authorities in order to involve so that people even interested.
\end{abstract}

Keywords: Islamic economy, alternative system, and justice.

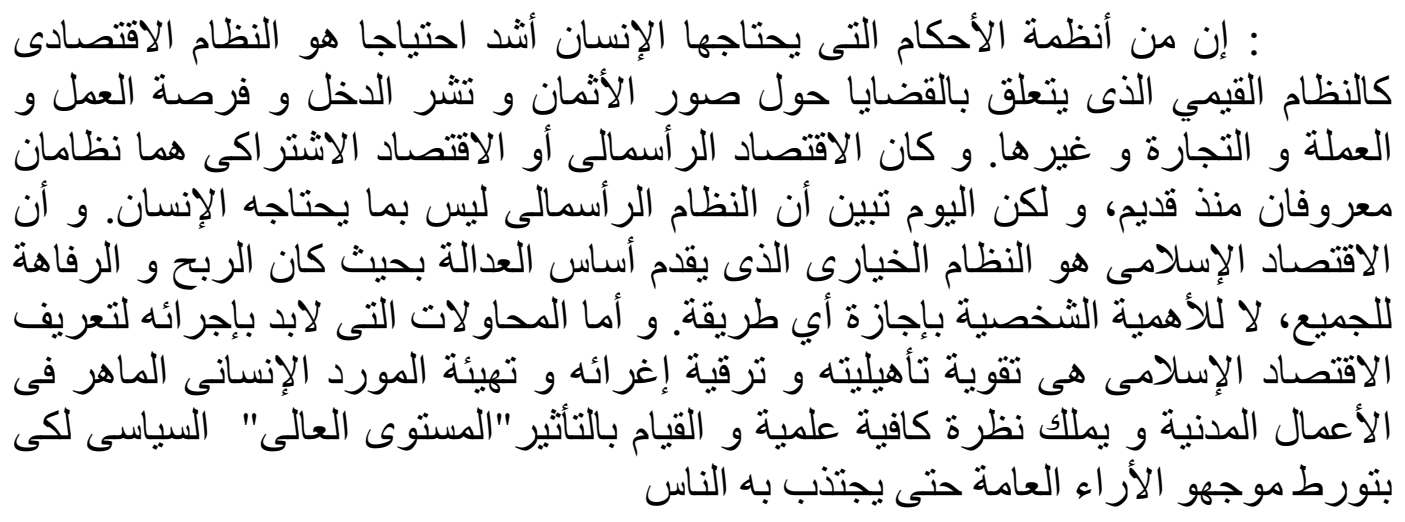

Problema dunia yang selalu menjadi perhatian utama manusia modern, kata Baqir al-Shadr, adalah pertanyaan tentang sistem apa yang paling sesuai untuk membangun kehidupan sosial umat manusia itu sendiri. Inilah pertanyaan paling pelik dan sangat sensitif yang selalu menghadang mereka sejak kehidupan sosialnya dimulai. Karena saling bekerjasama merupakan basis kehidupan sosial, maka diperlukan suatu sistem hukum untuk mengatur hubungan-hubungan antara sesama manusia tersebut. Semakin relevan dan semakin konsisten sistem itu dengan watak dan kepentingan-kepentingan manusia, maka ia akan semakin menjamin kemakmuran dan solidaritas masyarakat manusia dalam arti yang sesungguhnya.

Di antara sistem hukum kehidupan yang amat dibutuhkan oleh umat manusia tersebut adalah sistem ekonomi, sebagai sebuah sistem nilai yang pada prinsipnya menyangkut masalah-masalah di sekitar bentuk-bentuk harga, penyebaran pendapatan, kesempatan kerja, keuangan, perdagangan dan lain sebagainya. 
Seperti diketahui, sistem ekonomi kapitalis dan sosialis adalah sistem yang telah diperkenalkan dan dipraktekkan manusia modern sekian lama. Sejarah menunjukkan bahwa dalam persaingannya yang panjang, sistem ekonomi kapitalis ternyata mampu menyisihkan sistem yang disebut kedua, sehingga dunia sangat terikat dengan sistem itu. Tetapi kini kenyataan juga membuktikan bahwa sistem ekonomi kapitalis bukanlah sebuah sistem yang sesungguhnya dibutuhkan oleh umat manusia. Karena akibat sistem persaingan bebas yang dikembangkan dalam dunia ekonomi kapitalis tersebut, dunia menjadi ajang "peperangan" atau bahkan "pembunuhan", dimana seseorang atau suatu kelompok tertentu mengekploitasi yang lainnya secara bebas, sehingga yang didapatkan bukan kesejahteraan dan kebahagiaan bagi manusia, tetapi konplik dan bahkan peperangan yang berkepanjangan di antara sesama mereka. Banyak bukti yang kita dapati betapa sistem yang dulu sangat diagung-agungkan ternyata telah membuat dunia sarat dengan "permusuhan" yang dengan itu mereka menjadi semakin jauh dari kebahagiaan dan ketenangan yang sebenarnya. Melihat kepada kenyataan seperti itu, masyarakat dunia kini mulai melirik kepada sebuah sistem alternatif lain yaitu sistem ekonomi Islam.

\section{Apakah Ekonomi Islam itu?}

Seperti dikemukakan oleh al-Shadr, ekonomi Islam adalah ajaran Islam yang mengatur kehidupan ekonomi dari titik pandang tertentu tentang keadilan. Artinya, ekonomi Islam adalah sebuah sistem ekonomi yang mengedepankan azas keadilan, dimana keuntungan dan kesejahteraan untuk sesama menjadi tujuan utama dan bukan kepentingan-kepentingan pribadi dengan menghalalkan segala cara seperti yang umumnya berlaku di dunia kapitalis.

Ada dua prinsip utama yang dianut dalam sistem ekonomi Islam; pertama, prinsip pokok yang tidak boleh berubah; kedua, masalah-masalah praktis yang bersifat kebijakan-kebijakan dan dapat berubah sesuai dengan perkembangan masyarakat.

Hal-hal yang bersifat prinsip-prinsip pokok tersimpul kepada: Bahwa harta benda yang ada di alam ini adalah milik Allah, sementara manusia diberi amanah untuk menguasainya. Pesan ini, antara lain dapat kita lihat dalam alQur'an yang artinya "milik Allah semua apa yang ada di langit dan dibumi (li Allahi ma fi al-samawati wa ma fi al-ardh).

Bahwa jaminan dalam batas kecukupan diberikan kepada setiap individu di dalam masyarakat. Hal ini, antara lain, kita tangkap dalam surat al-Lahb, yang artinya "tahukah kalian orang-orang yang mendustakan agama? Itulah orang yang suka membentak anak yatim, dan tidak menganjurkan untuk memberi makan orang-orang miskin." Begitu juga dalam surat al-Zariyat ayat 19, yang artinya, "dan orang-orang yang dalam hartanya terdapat bagian tertentu untuk orang (miskin) yang meminta-meminta, dan orang-orang yang tidak punya (yang tidak mau meminta-minta). Nabi jua bersabda, yang artinya, "barang siapa yang meninggalkan keturunan yang lemah, hendaklah ia datang kepadaku, karena akulah (sebagai kepala negara) yang harus bertanggungjawab dan menjaminnya. (H.R.al-Hakim). Dan dalam hadisnya yang lain Nabi bersabda, 
"barang siapa meninggalkan keturunan (yang tersia-sia), maka datanglah kepadaku, sebab akulah (sebagai kepala negara) penanggungjawabnya.

Bahwa keadilan sosial dan pemeliharaan keseimbangan ekonomi diwujudkan bagi setiap individu masyarakat, sehingga modal tidak boleh beredar hanya di sekitar orang atau kelompok-kelompok tertentu saja. Hal ini secara tegas dijelaskan dalam al-Qur'an surat al-Hasyr ayat 7, yang artinya, "agar harta itu jangan hanya beredar di antara sesama orang-orang kaya saja di antara kamu". (kai la yakuna duulatan bain al-Agniya' minkum). Begitu juga dalam firman Allah yang lain yang artinya, "engkau ambil (zakat itu) dari orang-orang kaya mereka, dan berikan kepada orang-orang fakir di antara mereka".

Bahwa milik pribadi dihormati. Sesuai dengan firman Allah yang artinya, "laki-laki berhak mendapat bagian dari apa yang mereka usahakan dan perempuan juga berhak dari hasil yang mereka usahakan". Bahkan nabi lebih tegas lagi mengatakan bahwa "setiap muslim bagi muslim yang lain haram darahnya, hartanya dan kehormatannya". "Siapa yang terbunuh karena membela hartanya, maka ia mati syahid".

Bahwa kebebasan ekonomi itu terbatas. Di sini Islam mengharamkan beberapa aktivitas ekonomi yang mengandung unsur pemerasan, monopoli dan riba. Untuk itu Allah berfirman yang artinya, "dan janganlah kamu memakan harta di antara sesamamu dengan cara batil". "Allah menghalalkan jual beli dan mengharamkan riba". Nabi bersabda yang artinya, "barangsiapa melakukan monopoli suatu produk dengan maksud hendak menjualnya dengan harga mahal, maka ia telah melakukan kesalahan besar". (H.R. Muslim, Abu Daud dan Tirmidzi).

Bahwa Allah melarang prilaku boros, bermewah-mewah dan sombong, sesuai dengan firman-Nya, "Sesungguhnya para pemboros itu temannya syetan". "Kaum zalim hanya mementingkan kenikmatan dan kemewahan yang ada pada mereka. Mereka adalah orang-orang yang berdosa".

Kemudian hal-hal praktis yang bersifat kebijakan dan berubah-ubah adalah bagian yang berupa metode dan langkah teknis praktis, seperti bentuk-bentuk praktek ekonomi yang dinyatakan terlarang, bentuk-bentuk keuntungan yang tidak layak dan haram, batas keuntungan tentang upah minimum, campurtangan negara dalam aktivitas ekonomi dan hal-hal lain yang sifatnya berkaitan dengan zaman, tempat dan perubahan kondisi sosial.

Bila direnungi secara cermat, semua ayat atau hadis di atas menunjukkan betapa ajaran Islam dalam berekonomi sangat mengutamakan tegaknya nilainilai keadilan sebagai sebuah ajaran yang hampir-hampir tidak kita temui dalam sistem ekonomi kapitalis. Dan tanpa bermaksud apologetik dan menangisi masa lalu, ajaran inilah dahulu yang dipraktekkan Nabi bersama para saahabatnya dan beberapa dekade setelah itu di zaman klasik Islam, sehingga kemajuan ekonomi menjadi milik bersama, rahmatan li al-'alamin, bukan hanya milik segelintir orang seperti umumya terjadi di dunia kapitalisme.

Dengan pengalaman sejarah masa lalu itu juga, kini timbul keinginan di kalangan pebisnis, terutama dunia perbankan, mencoba menerapkan sistem ekonomi Islam dalam menjalankan bisnis lembaga keuangan mereka. Keinginan ke arah itu ternyata bukan hanya dengan menengok sejarah zaman klasik, tetapi kepada kenyataan empirik di lapangan ketika lembaga keuangan yang ditata 
dengan sistem kapitalis pada kolap dan berguguran di penghujung tahun 1990an diterpa badai krisis, lembaga-lembaga yang ditata dengan sistem ekonomi Islam ternyata aman dan tetap eksis tanpa harus direkapitalisasi seperti lembagalembaga keuangan konvensional lainnya.

\section{Prospek ekonomi Islam}

Sebagaimana terbaca di berbagai mas media, sistem ekonomi Islam mulai ramai diminati, terutama di lembaga-lembaga keuangan, seperti bank, asuransi, pasar multi level dan lain-lain. Bahkan tidak sedikit lembaga keuangan non milik muslim, termasuk yang berada di negara-negara luar negeri muslim, kini ikut menerapkan sistem ini, walau kemurnian dan kebenarannya masih perlu dipertanyakan. Di Indonesia misalnya, walau relativ terlambat dibanding beberapa negara lain, hampir semua bank konvensional sudah mulai membuka sistem perbankan syari' ah sebagai "anak perusahaannya". Asuransi jiwa dengan label syari'ah Islampun kini bermunculan di mana-mana, disamping berbagai bentuk kegiatan bisnis lain yang menggunakan label tersebut. Maka dilihat dari sisi ini,prospek perbankan syari'ah khususnya, ekonomi Islam pada umumnya cukup menjanjikan.

Namun, di balik prospek dalam perspektif kajian seperti di atas, kenyataan lapangan ternyata masih belum memberikan gambar cerah sebagaimana kita harapkan. Pertumbuhan lembaga-lembaga keuangan Islam ternyata masih kalah cepat bila dibanding dengan lembaga-lembaga konvensional yang memang sudah lama malang melintang di dunia bisnis dan keuangan itu sendiri. Maka pertanyaan yang agaknya segera harus kita jawab adalah mengapa hal itu terjadi dan bagaimana solusi keluarnya, sehingga sistem yang dinilai baik ini tidak hanya ada dalam wacana dan tidak ada manfaatnya secara nyata untuk umat, tetapi wujud dan ril dalam kenyataan, sehingga menjadi bukti bahwa Islam adalah agama yang benar-benar menjadi rahmat bagi seisi alam.

\section{Empat Tantangan Utama}

Saya pikir masih belum banyaknya umat Islam yang mengerti tentang ekonomi Islam, terutama perbankan Islam, adalah tantangan utama yang harus diresponi secara bijak dan konsepsional. Lalu masih kurang dan masih lemahnya daya tarik dari lembaga-lembaga keuangan itu adalah tantangan kedua yang perlu pula diakui dan dicarikan jalan keluarnya oleh internal lembaga bersangkutan. Kemudian masih langkanya Sumber Daya Manusia (SDM) yang benar-benar paham dengan sistem ekonomi Islam di internal lembaga-lembaga ekonomi Islam itu sendiri, sehingga masyarakat tidak merasa dapat pemahaman yang tepat tentang ekonomi Islam dan akhirnya menganggap lembaga ekonomi Islam adalah lembaga ekonomi konvensional yang memakai label atau simbolsimbol Islam saja, sementara substansinya tetap saja ekonomi konvensional. Dan adalah tantangan keempat yang cukup signifikan, dimana masyarakat tidak punya contoh yang akan diikuti untuk membuktikan bahwa sistem ekonomi Islam adalah sistem alternatif yang dinanti-nanti. 


\section{Langkah-langkah}

Maka saya pikir, langkah pertama untuk berbagai tantangan di atas adalah memperhebat sosialisasi dengan merangkul pihak-pihak yang lebih berpengaruh di semua strata masyarakat. Bahkan bila mungkin, perlu ada dana khusus sebagai penghargaan untuk setiap jasa yang dipakai itu (personal geransi). Kedua, tingkatkan daya tarik, karena setiap orang yang berbisnis, walau dengan syari'at atau ekonomi Islam sekalipun, pasti mengutamakan untung atau laba untuk dirinya. Untuk itu sebarkan "gula" agar semut terpancing dan berkerumun hendak mencoba. Ketiga, siapkan SDM yang tidak hanya skill dalam pekerjaan fisik, tetapi juga memiliki wawasan yang memadai secara ilmiah. Di sini, pendidikan khusus perlu dilakukan secara terus menerus. Dan ter akhir, lakukan lobi-lobi politik bisnis "tingkat tinggi" agar kaum pemegang opini publik ikut terlibat, sehingga masyarakatpun akhirnya juga berminat. Untuk itu agaknya diperlukan kiat dan orang-orang khusus sebagai "salesman".

\section{Kesimpulan}

Kesimpulan kecil yang dapat dikemukakan dalam wacana ini adalah bahwa secara makro, prospek ekonomi Islam ke depan cukup cerah dan menjanjikan, tidak hanya untuk keuntungan pribadi, tetapi untuk bersama dalam arti yang sesungguhnya. Tetapi karena masih kurang dipahami dan masih kurang daya tarik, akhirnya sistem nilai ini masih kurang pula diminati. Oleh sebab itu, semua pihak yang ingin agar sistem ekonomi Islam benar-benar manjadi tawaran konstruktif untuk kebangkitan umat dan bangsa, perlu bekerja lebih keras lagi sehingga nilai-nilai Islam tentang ekonomi tidak hanya sekedar wacana, tetapi mewujud sebagai rahmat dalam arti yang sesungguhnya. 